\title{
Biological activity of 7ß-acetoxywithanolide D isolated from Acnistus arborescens
}

\section{Atividade biológica de 7ß-acetoxivitanolido D isolado de Acnistus arborescens}

\author{
Joze Aparecida Marciano Corrêa ${ }^{1}$; Diana Fortkamp ${ }^{1}$; Camila Furtunato da Silva ${ }^{2}$; \\ Flávio Rocha ${ }^{1}$; Luiz Humberto Gomes ${ }^{3}$; Keila Maria Roncato Duarte ${ }^{4}$; \\ Antonio Gilberto Ferreira ${ }^{5}$; Simone Possedente de Lira ${ }^{6 *}$
}

\begin{abstract}
Many oomycete species are plant pathogens and are responsible for causing significant losses in agriculture. Currently, plant pathogen control is carried out by chemical, biological and physical methods. However, due to the development of resistance to these methods by some pathogens, it is imperative that alternative methods are developed. Brazilian biodiversity is well-known for its species richness and is considered a promising source of natural products. Among the vascular plants, the family Solanaceae A. Juss. (Solanaceae) is considered one of the largest, with distributions across all tropical and temperate regions of the world. The Solanaceae family presents a high diversity of species of economic importance as sources of food, medicinal and ornamental properties. Plants of this family are sources of secondary metabolites of various chemical classes that possess potential diverse applications. Therefore, chemical and biological investigations of these compounds are extremely important as they present alternatives for their potential use in the control of plant pathogens. Here, we report for the first time, the biological activity of $7 \beta$-acetoxywithanolide D, a compound isolated from Acnistus arborescens, against the oomycete Phytophthora cinnamomi. With these results, we emphasize the importance of such studies on plant secondary metabolites, which may present coadjuvant options in the control of plant pathogens.

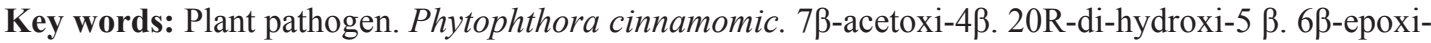
1-oxo-vita-2,24-dienolido. Secondary metabolites. Solanaceae.
\end{abstract}

\section{Resumo}

Muitas espécies de oomicetos são fitopatógenos e responsáveis por causar perdas significativas na agricultura. Atualmente, o controle de fitopatógenos é realizado por métodos químicos, biológicos e físicos. No entanto, alguns agentes patogênicos adquirem resistência a esses métodos, por isso é

\footnotetext{
${ }^{1}$ Discentes, Curso de Doutorado do Programa de Pós-Graduação em Microbiologia Agrícola, Universidade de São Paulo, Escola Superior de Agricultura "Luiz de Queiroz", USP/ESALQ, Departamento de Ciências Exatas, Piracicaba, SP, Brasil. E-mail: jacorrea@usp.br; dianafortkamp@usp.br; flaviorocha@usp.br

2 Discente, Curso de Graduação em Ciências dos Alimentos, USP/ESALQ, Departamento de Ciências Exatas, Piracicaba, SP, Brasil. E-mail: cmila.fsilva@gmail.com

3 Pesquisador, USP/ESALQ, Departamento de Ciências Exatas, Piracicaba, SP, Brasil. E-mail: luhgomes1@usp.br

4 Pesquisadora, Unidade de Pesquisa de Tietê, APTA Regional Polo Centro Sul, Tietê, SP, Brasil. E-mail: keila@apta.sp.gov.br

5 Prof. Titular, Universidade Federal de São Carlos, UFSCar, Departamento de Química, São Carlos, SP, Brasil. E-mail: giba@ ufscar.br

6 Prof $^{a}$ Dr $^{\mathrm{a}}$, USP/ESALQ, Departamento de Ciências Exatas, Piracicaba, SP, Brasil. E-mail: splira@usp.br

* Author for correspondence
} 
necessário desenvolver constantemente alternativas para controlá-los. A biodiversidade brasileira é conhecida devido à sua riqueza de espécies, sendo considerada uma fonte promissora de produtos naturais. Entre as plantas vasculares, a família Solanaceae A. Juss. (Solanaceae) é considerada uma das maiores, apresentando distribuição em todas as regiões tropicais e temperadas do mundo. A família Solanaceae apresenta alta diversidade de espécies de importância econômica como fonte de alimentos, propriedades medicinais e ornamentais. As plantas desta família são fontes de metabolitos secundários de várias classes químicas com as mais diversas aplicações. Portanto, as investigações químicas e biológicas desses compostos são extremamente importantes e podem se tornar uma alternativa para o controle dos agentes patogênicos das plantas. Aqui, relatamos pela primeira vez a atividade biológica do composto $7 \beta$-acetoxivitanolido D isolado de Acnistus arborescens contra o oomiceto Phytophthora cinnamomi. Com este resultado, enfatizamos a importância de estudos com metabolitos secundários de plantas, que podem ser uma opção coadjuvante no controle de fitopatógenos.

Palavras-chave: Fitopatógeno. Phytophthora cinnamomi. $7 \beta$-acetoxi-4 $\beta$. 20R-di-hidroxi-5 $\beta$. 6p-epoxi1-oxo-vita-2,24-dienolido. Metabólitos secundários. Solanáceas.

Plants of the family Solanaceae A. Juss, comprising approximately 2,500 to 3,000 species distributed in 96 genera, are known to produce several bioactive compounds with potential activity against plant pathogens (D'ARCY, 1991; KIM et al., 2016).

The oomycete plant pathogen, Phytophthora cinnamomi, affects numerous crops and causes a highly destructive root rot (RIOS et al., 2016). This pathogen infects more than 3,000 species of plants, such as avocado, pineapple, peach, trees, woody shrubs and herbs. P. cinnamomi usually causes rotting of roots and can also cause stem cankers and the dieback of young plants. The number of plant species known to be susceptible to $P$. cinnamomi has increased considerably in the last 30 years. In addition to crop damage, P. cinnamomi also affects natural ecosystems (HARDHAM, 2005). The oomycete is among the list of 100 worst invasive foreign species and has become an invasive species in several ecosystems mainly due to its transport with fruits and vegetables (BURGESS et al., 2017).

Currently, market products with compounds such as phenylamides and phosphonates are available that exhibit inhibitory action against $P$. Cinnamoni growth. However, the problems with their use include their biodegradability in soils and the emergence of pathogen isolates resistant to these compounds (LUCAS et al., 1990).
Thus, there is a necessity for the discovery of novel compounds that are effective against the oomycete $P$. cinnamomi.

The experiments were conducted at the Laboratório de Química Orgânica de Produtos Naturais of the Escola Superior de Agricultura 'Luiz de Queiroz' (ESALQ-USP), Piracicaba-SP, Brazil, and at the Laboratório de Ressonância Magnética Nuclear, in the Universidade Federal de São Carlos (UFSCAR), São Carlos-SP, Brazil.

The ${ }^{1} \mathrm{H}$ and ${ }^{13} \mathrm{C}$ nuclear magnetic resonance (NMR) data were generated on a Bruker 14.1 Tesla AVANCE III-400 model spectrometer with cryoprobe $^{\mathrm{TM}}$ operating at $400 \mathrm{MHz}$ and $100 \mathrm{MHz}$, respectively. The chemical shifts were given on a $\delta$ (ppm) scale and referenced to the TMS. The samples were solubilized in $\mathrm{CDCl}_{3}(\delta 7.26 \mathrm{ppm})$.

High-resolution electrospray ionization mass spectrometry (HR-ESIMS) data were acquired on a Micromass ZQ2000, under the following conditions: capillary voltage, $3 \mathrm{kV}$; operating in electrospray positive mode; detection range, 150$1500 \mathrm{Da}$ with total ion count extracting acquisition. Data analysis was performed using Bruker Compass Data Analysis 4.2.

High-performance liquid chromatography (HPLC) was conducted using an Agilent 1100 Series UV/Vis with a quaternary pump, coupled to a UV 
detector MWD (Multiple Wavelength Detector), using a $\mathrm{C}_{18}$ reverse phase column $(4.6 \times 250 \mathrm{~mm}, 5$ $\mu \mathrm{m}$, Agilent ${ }^{\circledR}$ Zorbax Eclipse), with a $\mathrm{H}_{2} \mathrm{O} / \mathrm{MeOH}$ $(30: 70, \mathrm{v} / \mathrm{v})$ mobile phase, flow rate of $1 \mathrm{~mL} \mathrm{~min}^{-}$ 1 , and wavelength $(\lambda)$ of $254 \mathrm{~nm}$. HPLC-grade solvents were utilized. Solid-phase extraction was carried out using silica gel cartridges of different dimensions (Phenomenex). Gel permeation chromatography was performed in a glass column filled with Sephadex LH-20 (Pharmacia Biotech). Silica gel $_{254}$ (Macherey-Nagel) was used for thin layer chromatography (TLC). Spots were detected under UV light (254 and $365 \mathrm{~nm}$ ) and stained with the reagents Dragendorff and phosphomolybdic acid (PMA).

The leaves of the Solanaceae plants Acnistus arborescens, Lycianthes rantonnei, Solanum americanum, and Cestrum intermedium were collected in Piracicaba - SP, in May 2013. All the plants were authenticated by Prof. Dr. Vinicius C. Souza, from São Paulo University. The vouchers specimens were deposited at the ESA (Herbarium collection of ESALQ), Piracicaba - SP.

The leaves were detached, washed and dried at $40{ }^{\circ} \mathrm{C}$, and then crushed. The powder was extracted by infusion in distilled water at $100{ }^{\circ} \mathrm{C}$ and then filtered, yielding a crude extract, at a concentration of $2 \%(\mathrm{w} / \mathrm{v})$.

The crude extract of the selected plant was subjected to 3 separate liquid-liquid partitions between water and the organic solvents n-butanol, ethyl acetate and $\mathrm{CH}_{2} \mathrm{Cl}_{2}$. The obtained fractions were used in $P$. cinnamomi bioassays. The bioactive butanolic fraction was further purified over Sephadex LH-20 by elution with $\mathrm{MeOH}$ to yield 13 fractions, which were combined in 10 resulting fractions according to the TLC analysis data. The active fraction, AA4, was subjected to a silica gel cartridge eluted with a $\mathrm{CH}_{2} \mathrm{Cl}_{2}: \mathrm{MeOH}$ gradient, resulting in 5 fractions (AA4A-AA4E). The bioactive fraction, AA4A, was fractionated in a silica gel cartridge $\left(\mathrm{CH}_{2} \mathrm{Cl}_{2}: \mathrm{MeOH}\right.$ gradient $)$ to yield 6 fractions (AA4A1-AA4A6). The bioactive fraction, AA4A1, was purified by reversed-phase HPLC using a $\mathrm{H}_{2} \mathrm{O} / \mathrm{MeOH}(30: 70)$ mobile phase to obtain the active compound AA4A1C.

The evaluation of crude extracts was performed by the agar diffusion method, where a microorganism is challenged with a biologically active substance in a solid culture medium. This test correlates the size of the growth inhibition zone of the challenged microorganism with the concentration of the test substance (BARRY; THORNSBERRY, 1991). The crude extracts of the solanaceous leaves were incorporated into a potato-dextrose-agar (PDA) culture medium $(20 \%$ potato, $2 \%$ dextrose and $2 \%$ agar, adjusted to $\mathrm{pH} 7.0-7.5)$ at $2 \%(\mathrm{w} / \mathrm{v})$ final concentrations and were sterilized by autoclaving at $121{ }^{\circ} \mathrm{C}$ for 20 minutes. The media was then poured $(10 \mathrm{ml})$ into Petri dishes $(60 \times 15 \mathrm{~mm})$. After solidification of the culture medium, a mycelial disk $(0.7 \mathrm{~cm})$ of the plant pathogen was placed on the medium; then, the petri dishes were closed and kept in an incubator chamber type B.O.D. at $25{ }^{\circ} \mathrm{C} \pm 2$ ${ }^{\circ} \mathrm{C}$ with a 12-hour photoperiod for 7 days. After the incubation period, the mycelial growth of the plant pathogen was evaluated.

Biological assays of agar diffusion were performed in a completely randomized design with three replicates (each plate being an experimental unit). The data were subjected to analysis of variance, and the mean values were compared by the Tukey test at 5\% probability. All statistical analysis was performed in the ASSISTAT ${ }^{\circledR}$ version 7.6 beta program.

The paper disk method was used to determine the antioomycete activity during the purification procedures. Each obtained fraction was applied to a $0.6 \mathrm{~cm}$ diameter sterile paper disk (with $2 \mathrm{mg}$ of each extract, $1 \mathrm{mg}$ of each fraction or $0.5 \mathrm{mg}$ of each pure compound). An inoculum of the P. cinnamomi pathogen (a $0.7 \mathrm{~cm}$ diameter disc removed from the edge of a newly streaked plate) was added to another edge of the PDA plate. The clear inhibition zones 
of mycelial growth around the paper disks were measured after incubation for 7 days at $25^{\circ} \mathrm{C} \pm 2{ }^{\circ} \mathrm{C}$ with a 12-hour photoperiod. After this period, the inhibition percentages were calculated and compared to the control (BARRY; THORNSBERRY, 1991). The bioassays with fractions and pure compounds were done in simplicate.

Ofthe four Solanaceae family plant crude extracts, only the $A$. arborescens extract demonstrated any activity against $P$. cinnamomi mycelial growth in bioassays (100\% inhibition), as shown in Figure 1A. The other 3 extracts had no activity ( $0 \%$ inhibition) against this oomycete. Studies have shown that plants belonging to the genus Acnistus harbor various chemical components, such as flavonoids, alkaloids, and terpenes, among others, and many of these compounds may have activity against microorganisms (ROUMY et al., 2010).

Figure 1. A) Biological activity of four extracts of plants (Solanaceae family) incorporated at $2 \%(\mathrm{w} / \mathrm{v})$ in the culture medium against the oomycete Phytophthora cinnamomi. B) Antioomycete activity assay against $P$. cinnamomi evaluating fractions from HPLC ( $0.5 \mathrm{mg}$ per paper disk) after 7 days of incubation in B.O.D.

A)

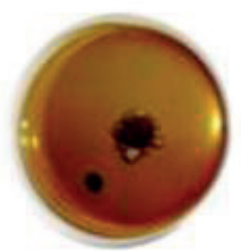

Acnistus arborescens

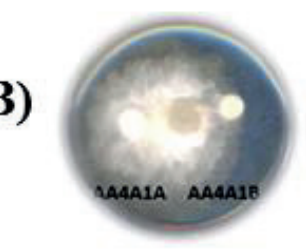

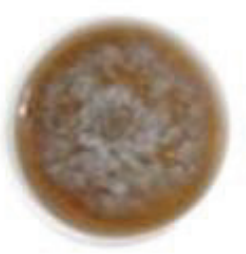

Cestrum intermedium

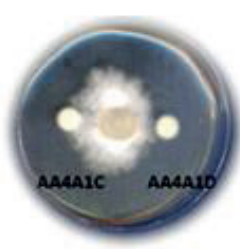

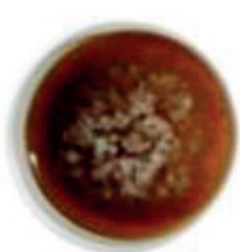

Solamum americamum

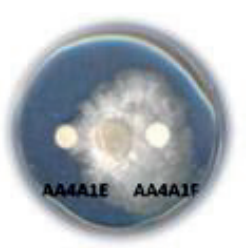

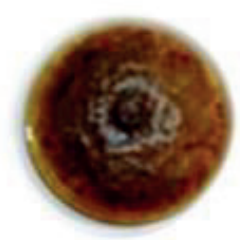

Lycianthes rantonnei

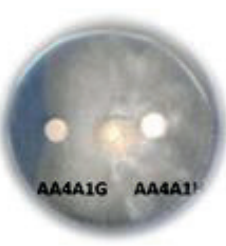

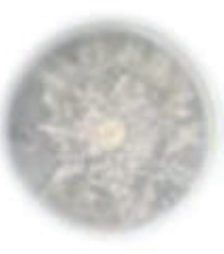

Negative

control

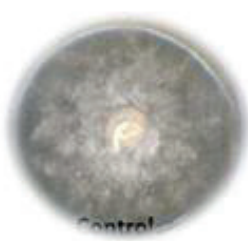

The crude extract of $A$. arborescens was subjected to liquid-liquid partition. The obtained fractions were then assayed by the disk diffusion method, and the n-butanol fraction (76\% activity), ethyl acetate (74\% activity) and dichloromethane (68\% activity) were found to be active against $P$. cinnamomi. The n-butanol fraction was subjected to a permeation gel chromatography on Sephadex LH-20 to obtain 13 fractions (AA1-AA13). The AA4 active fraction (133 mg) was subjected to a silica Sep-Pak column to give five fractions (AA4A-AA4E). The AA4A active fraction (81 $\mathrm{mg}$ ) was subjected to a chromatographic separation to obtain 6 fractions (AA4A1-AA4A6). The AA4A1 active fraction $(9.7 \mathrm{mg})$ was subjected to
HPLC separation to give 8 fractions (AA4A1AAA4A1H). The obtained fractions were assayed by the disk diffusion method against $P$. cinnamomi (0.5 mg compound disk ${ }^{-1}$ ), Figure 1B. As evident from the figure, three fractions were more active in the bioassay (AA4A1C, AA4A1D and AA4A1E). However, the AA4A1D and AA4A1E fractions possessed a large number of compounds and a small amount of mass in mg. Thus, the AA4A1C fraction $(1.8 \mathrm{mg})$ containing only one compound (pure) and $78.5 \%$ of the activity was chemically characterized.

The compound AA4A1C had a $\mathrm{UV}_{\max }$ at $210 \mathrm{~nm}$. In the high-resolution mass spectrum, we observed molecular ions at $\mathrm{m} / z 529.2793[\mathrm{M}+\mathrm{H}]^{+}$that were 
appropriate for the molecular formula $\mathrm{C}_{30} \mathrm{H}_{40} \mathrm{O}_{8}$ (528.2714 Da).

With the data obtained in the ${ }^{1} \mathrm{H}$ NMR and ${ }^{13} \mathrm{C}$ NMR spectrum (Table 1), it was possible to correlate the hydrogen and carbon shifts $\left(\delta_{\mathrm{H}}\right)$ of AA4A1C with the compound $7 \beta$-acetoxywithanolide $\mathrm{D}$ (Figure 2), also known as $7 \beta$-acetoxy- $4 \beta, 20 R$ dihydroxy- $\quad 5 \beta, 6 \beta$-epoxy-1-oxo-witha-2,24dienolide) (MINGUZZI et al., 2002).

Table 1. ${ }^{1} \mathrm{H}$ NMR and ${ }^{13} \mathrm{C}$ NMR data for compound AA4A1C and 7 $\beta$-acetoxywithanolide D.

\begin{tabular}{|c|c|c|c|c|}
\hline & $\begin{array}{c}\text { 7ß-acetoxywithanolide D } \\
\text { Minguzzi et al. (2002); } \\
500 \mathrm{MHz} \\
\end{array}$ & $\begin{array}{c}7 \beta \text {-acetoxywithanolide D } \\
\text { Minguzzi et al. (2002); } \\
100 \mathrm{MHz} \\
\end{array}$ & $\begin{array}{c}\mathrm{AA} 4 \mathrm{~A} 1 \mathrm{C} \\
400 \mathrm{MHz} ; \mathrm{CDCl}_{3}\end{array}$ & $\begin{array}{c}\mathrm{AA} 4 \mathrm{~A} 1 \mathrm{C} \\
100 \mathrm{MHz}, \mathrm{CDCl}_{3}\end{array}$ \\
\hline $\mathrm{N}^{\circ} \mathrm{C}$ & $\delta \mathrm{H}($ mult, $J \mathrm{~Hz})$ & $\delta \mathrm{C}$ & $\delta \mathrm{H}$ (mult, $J \mathrm{~Hz}$ ) & $\delta \mathrm{C}$ \\
\hline 1 & & 201.13 & & 201.0 \\
\hline 2 & $6.20 \mathrm{~d}(10.0)$ & 132.33 & $6.22 \mathrm{~d}(10.0)$ & 132.3 \\
\hline 3 & $6.96 \mathrm{dd}(5.9 ; 10.0)$ & 141.57 & $6.94 \mathrm{dd}(5.9 ; 9.9)$ & 141.5 \\
\hline 4 & $3.80 \mathrm{~d}(5.9)$ & 69.30 & $3.76 \mathrm{~d}(5.7)$ & 69.3 \\
\hline 5 & & 67.02 & & 66.9 \\
\hline 6 & $3.34 \mathrm{~d}(1.8)$ & 62.41 & $3.34 \mathrm{~d}(2.0)$ & 62.5 \\
\hline 7 & $4.84 \mathrm{dd}(9.3 ; 1.8)$ & 74.56 & $4.85 \mathrm{dd}(2.0 ; 9.7)$ & 74.6 \\
\hline 8 & $1.82(9.3)$ & 34.06 & $1.79 \mathrm{~d}(9.6)$ & 34.1 \\
\hline 9 & 1.21 & 43.32 & $1.21 \mathrm{~m}$ & 43.3 \\
\hline 10 & & 46.87 & & 46.9 \\
\hline 11 & $1.48,1.86$ & 22.12 & $1.51,1.85 \mathrm{~m}$ & 22.2 \\
\hline 12 & $1.20,1.98$ & 39.47 & $1.21,1.99 \mathrm{~m}$ & 39.5 \\
\hline 13 & & 43.52 & & 43.5 \\
\hline 14 & 1.10 & 55.52 & $1.10 \mathrm{~m}$ & 55.5 \\
\hline 15 & 1.45 & 25.55 & $1.44 \mathrm{~m}$ & 25.6 \\
\hline 16 & 1.25 & 29.69 & $1.25 \mathrm{~m}$ & 29.8 \\
\hline 17 & 1.39 & 53.82 & $1.39 \mathrm{~m}$ & 53.8 \\
\hline 18 & 0.89 & 13.45 & $0.88 \mathrm{~s}$ & 13.5 \\
\hline 19 & 1.44 & 17.18 & $1.44 \mathrm{~s}$ & 17.2 \\
\hline 20 & & 74.96 & & 75.0 \\
\hline 21 & 1.27 & 20.80 & $1.26 \mathrm{~s}$ & 20.9 \\
\hline 22 & $4.18 \mathrm{dd}(3.4 ; 13.4)$ & 80.82 & $4.17 \mathrm{dd}(3.6 ; 13.3)$ & 80.8 \\
\hline 23 & $2.06,2.41$ & 31.48 & $2.11,2.43 \mathrm{~m}$ & 31.5 \\
\hline 24 & & 148.82 & & 148.8 \\
\hline 26 & & 121.99 & & 122.0 \\
\hline 28 & & 165.96 & & 165.9 \\
\hline 25 & 1.88 & 12.46 & $1.88 \mathrm{~s}$ & 12.5 \\
\hline 27 & 1.94 & 20.55 & $1.94 \mathrm{~s}$ & 20.6 \\
\hline 7-OAc & & 171.25 & & 171.2 \\
\hline 7-OAc & 2.11 & 21.52 & $2.16 \mathrm{~s}$ & 21.5 \\
\hline
\end{tabular}


Figure 2. 7 $\beta$-acetoxywithanolide D (CAS 30655-47-1).

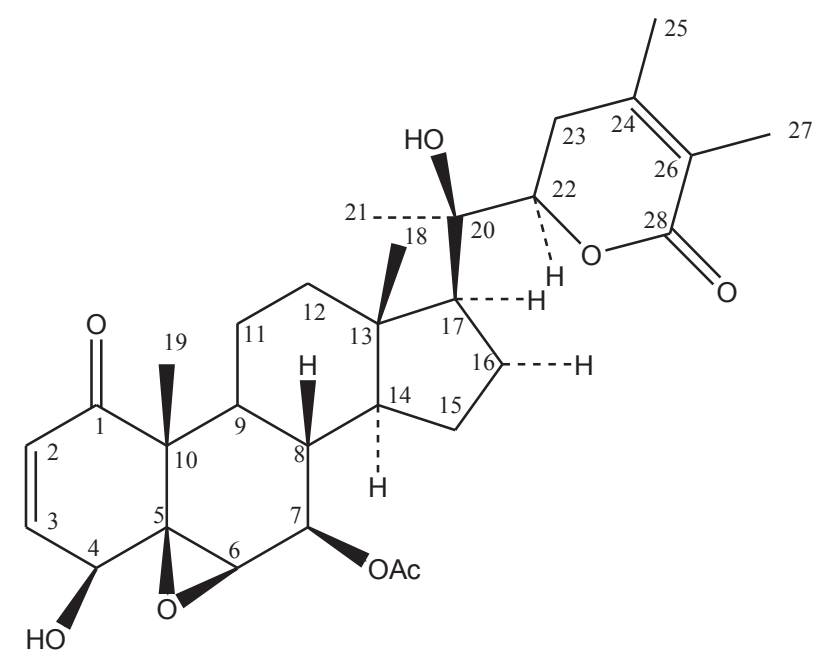

The withanolides are the most abundant group of compounds with a $\delta$ lactone-containing side chain. Their basic structure is a C-28 ergostane with a modified side chain forming a $\delta$-lactone between carbons 22 and 26. This group has been isolated from many plants, most of which belong to the Solanaceae family (MISICO et al., 2011). Examples of plants that are sources of withanolides are Solanum capsicoides (CHEN et al., 2015), Datura metel (YANG et al., 2014), Aurelian fasciculata var. fasciculate (ALMEIDA-LAFETA et al., 2010), and Withania obtusifolia (ALALI et al., 2014), among others.

In studies conducted on $A$. arborescens where withanolides were isolated, the following were reported: cytotoxic activities (CORDERO, et al., 2009; MINGUZZI et al., 2002; ROUMY et al., 2010), antifungal activity against Pneumocystis carinii (ROUMY et al., 2010), and antitrypanosome, leishmanicidal and antibacterial activities (MISICO et al., 2011).

The biological effects of $7 \beta$-acetoxywithanolide $D$ include anticancer and cytotoxic activities (MINGUZZI et al., 2002, 2011), with $\mathrm{ED}_{50}$ values ranging from 0.03 and $1.3 \mathrm{mg} \mathrm{ml}^{-1}$ for human breast cancer, human lung cancer, human colon cancer, human oral epidermoid carcinoma, vinblastine- resistant $\mathrm{KB}$ cell line and hormone-dependent human prostate cancer.

The withanolide, 7- $\beta$-acetoxywithanolide D, was isolated from the plant $A$. arborescens. To our knowledge, this is the first report of the antioomycete activity of this withanolide against the plant pathogen P. cinnamomi. Studies regarding the toxicity of the compound and the environmental risks are still necessary. Therefore, the 7- $\beta$-acetoxywithanolide $\mathrm{D}$ demonstrated promising antioomycete activity and may be considered for application as an agrochemical after the toxicity and in vivo tests.

\section{Acknowledgments}

Financial support was provided by FAPESP grants: BIOTA/BIOprospecTA: 2013/502288, FAPESP 2014/15760-3) and CNPq grant (161867/2011-1). Scholarships from FAPESP for F. Rocha (2012/02861-0) and C. F. da Silva (2011/09349-0), CAPES and CNPq (142079/20162) for D. Fortkamp are also gratefully acknowledged. We thank Dr. R. G. de S. Berlinck for the support, Dr. N. S. Massola Júnior and Dra. L. de D. Teixeira for the plant pathogens, and Dr. V. C. Souza and D. Gissi for the identification of Solanaceae species. 


\section{References}

ALALI, F. Q.; AMRINE, C. S. M.; EL-ELIMAT, T.; ALKOFAHI, A.; TAWAHA, K.; GHARAIBAH, M.; SWANSON, S. M.; FALKINHAM III, J. O.; CABEZA, M.; SÁNCHEZ, A.; FIGUEROA, M.; OBERLIES, N. H. Bioactive withanolides from Withania obtusifolia. Phytochemistry Letters, Amsterdam, v. 9, n. 1, p. 96-101, 2014.

ALMEIDA-LAFETA, R. C.; FERREIRA, M. J. P.; EMERENCIANO, V. P.; KAPLAN, M. A. C. Withanolides from Aureliana fasciculata var. fasciculata. Helvetica Chimica Acta, Basel, v. 93, n. 12, p. 24782487, 2010.

BARRY, A. L.; THORNSBERRY, C. Susceptibility tests: diffusion test procedures. In: BALOWS, A.; HAUSER, W. J. (Ed.). Manual of clinical microbiology. Washington: ASM Press, 1991. p. 1117-1125.

BURGESS, T. I.; SCOTT, J. K.; MCDOUGALL, K. L.; STUKELY, M. J. C.; CRANE, C.; DUNSTAN, W. A.; BRIGG, F.; ANJIC, V.; WHITE, D.; RUDMAN, T.; ARENTZ, F.; OTA, N.; HARDY, G. E. S. J. Current and projected global distribution of Phytophthora cinnamomi, one of the world's worst plant pathogens. Global Change Biology, Oxford, v. 23, n. 4, p. 1661-1674, 2017.

CHEN, B. W.; CHEN, Y. Y.; LIN, Y. C.; HUANG, C. Y.; UVARANI, C.; HWANG, T.; CHIANG, M. Y.; LIUG, H. Y.; SHEU, J. H. Capsisteroids A-F, withanolides from the leaves of Solanum capsicoides. RSC Advances, Cambridge, v. 5, n. 108, p. 88841-88847, 2015.

CORDERO, C. P.; MORANTES, S. J.; PÁEZ, A.; RINCÓN, J.; ARISTIZÁBAL, F. A. Cytotoxicity of withanolides isolated from Acnistus arborescens. Fitoterapia, Milano, v. 80, n. 6, p. 364-368, 2009.

D'ARCY, W. G. The Solanaceae since 1976, with a review of its biogeography. In: HAWKES, J. G.; LESTER, R. N.; NEE, M.; ESTRADA, N. (Ed.). Solanaceae III taxonomy, chemistry, evolution. Kew: Royal Botanic Gardens, 1991. p. 75-137.

HARDHAM, A. R. Phytophthora cinnamomi. Molecular Plant Pathology, Oxford, v. 6, n. 6, p. 589-604, 2005.
KIM, H. G.; BAE, J. H.; JASTRZEBSKI, Z.; CHERKAS, A.; HEO, B.-G.; GORINSTEIN, S.; KU, Y.-G. Binding, antioxidant and anti-proliferative properties of bioactive compounds of sweet paprika (Capsicum annuum L.). Plant Foods for Human Nutrition, Dordrecht, v. 71, n. 2, p. 129-136, 2016.

LUCAS, J. A.; BOWER, L. A.; COFFEY, M. D. Fungicide resistance in soil-borne Phytophthora species. EPPO Bulletin, Paris, v. 20, n. 1, p. 199-206, 1990.

MinguZZI, S.; BARATA, L. E. S.; CORDELL, G. A. Derivados citotóxicos de vitanolidos isolados das folhas de Acnistus arborescens. Quimica Nova, São Paulo, v. 34, n. 2, p. 237-241, 2011.

MINGUZZI, S.; BARATA, L. E. S.; SHIN, Y. G.; JONAS, P. F.; CHAI, H.-B.; PARK, E. J.; PEZZUTO, J. M.; CORDELL, G. A. Cytotoxic withanolides from Acnistus arborescens. Phytochemistry, New York, v. 59, n. 6, p. 635-641, 2002.

MISICO, R. L.; NICOTRA, V. E.; OBERTI, J. C.; BARBOZA, G.; GIL, R. R.; BURTON, G. Withanolides and related steroids. Chapter: progress in the chemistry of organic natural products. Fortschritte der Chemie Organischer Naturstoffe, Vienna, v. 94, n. 1, p. 127-229, 2011.

RIOS, P.; OBREGON, S.; DE HARO, A.; FERNANDEZREBOLLO, P.; SERRANO, M. S.; SANCHEZ, M. E. Effect of Brassica biofumigant amendments on different stages of the life cycle of Phytophthora cinnamomi. Journal of Phytopathology, Berlin, v. 164, n. 9, p. 582594, 2016.

ROUMY, V.; BIABIANY, M.; HENNEBELLE, T.; ALIOUAT, E. M.; POTTIER, M.; JOSEPH, H.; JOHA, S.; QUESNEL, B.; ALKHATIB, R.; SAHPAZ, S.; BAILLEUL, F. Antifungal and cytotoxic activity of withanolides from Acnistus arborescens. Journal of Natural Products, Cincinnati, v. 73, n. 7, p. 1313-1317, 2010 .

YANG, B. Y.; XIA, Y. G.; LIU, Y.; LI, L.; JIANG, H.; YANG, L.; WANG, Q. H.; KUANG, H. X. New antiproliferative and immunosuppressive withanolides from the seeds of Datura metel. Phytochemistry Letters, Amsterdam, v. 8, n. 1, p. 92-96, 2014. 
